\title{
Examining factors associated with treatment completion in a community-based program for individuals with criminal justice involvement
}

\author{
Lisa M Shannon ${ }^{1 *}$, Afton Jackson $^{1}$, Jennifer Newell ${ }^{1}$, Elizabeth Perkins ${ }^{1}$, Connie Neal $^{2}$ \\ From 2014 Addiction Health Services Research (AHSR) Conference \\ Boston, MA, USA. 15-17 October 2014
}

\section{Background}

Drug court provides community-based treatment to individuals with substance abuse problems involved in the criminal justice system. The program offers comprehensive treatment as an alternative to incarceration. Past research has suggested there are sociodemographic and other personal characteristics that may impact an individual's success in this type of program. The purpose of the current study is to examine factors associated with treatment completion among a random sample of program participants.

\section{Methods}

A stratified random sample $(\mathrm{n}=534)$ was selected from the total participants in Kentucky Drug Courts (KDC; $\mathrm{N}=4881$ ) from July 1,2006 , to January 1,2011 . The stratification was utilized to ensure participants were selected from all KDC sites, proportionate to the percentage the site represented of the total KDC population. Data utilized for these analyses were gathered from: the baseline assessment at program entry (a modified version of the Addiction Severity Index (ASI); [1]) and the KDC Management Information System, which contains comprehensive information on services and activities during program participation. The majority of the sample was male $(60.3 \%)$ and, on average, about 30 years old $($ mean $=29.5 ; \mathrm{SD}=8.7)$.

\section{Results}

Overall, of the 534 individuals selected as part of the stratified random sample, 36.3 percent were program

\footnotetext{
* Correspondence: I.shannon@moreheadstate.edu

'Sociology, Social Work and Criminology, Morehead State University, Morehead, KY, 40351, USA

Full list of author information is available at the end of the article
}

graduates $(\mathrm{n}=194)$. Enter binary logistic regression was utilized to examine factors associated with program completion. There were several variables positively associated with program completion including: increased age $(\mathrm{p}<.001)$, reporting race as Caucasian $(\mathrm{p}=.015)$, being single/never married $(\mathrm{p}=.004)$, no past history of alcohol/drug treatment $(\mathrm{p}=.019)$, not reporting a pension for psychiatric disability $(\mathrm{p}=.007)$, no referrals to shortterm residential treatment $(\mathrm{p}=.033)$, and not having any programmatic sanctions $(\mathrm{p}=.002)$. There were several variables negatively associated with program completion including: having less than a high school diploma $(\mathrm{p}=.038)$, being unemployed $(\mathrm{p}=.011)$, no referrals to outpatient substance abuse treatment ( $\mathrm{p}<$ $.001)$, and number of positive drug tests $(\mathrm{p}=.019)$.

\section{Conclusions}

Understanding factors associated with program completion is important for multiple levels of programming. First, identifying characteristics of individuals most associated with program graduation can help with targeting screening and program assessment. Further, identifying characteristics of individuals most associated with program noncompliance can help with identifying individuals most at risk within the program to develop appropriate treatment and service planning.

\footnotetext{
Acknowledgements

Financial support for this research was provided by a Bureau of Justice Assistance (BJA) grant (Principal Investigator: Lisa Shannon). The views expressed are attributed to the authors and do not necessarily reflect the opinion of the funding agency or other collaborative partners.

\section{Authors' details}

${ }^{1}$ Sociology, Social Work and Criminology, Morehead State University, Morehead, KY, 40351, USA. ²Department of Statewide Services, Kentucky Drug Courts, Administrative Office of the Courts, Frankfort, KY, 40601, USA.
} 
Published: 20 February 2015

\section{Reference}

1. McLellan A, Luborsky L, Woody G, O'Brien C: An improved diagnostic evaluation instrument for substance abuse patients. J Nervous Mental Disorders 1980, 168:26-33.

doi:10.1186/1940-0640-10-S1-A60

Cite this article as: Shannon et al:: Examining factors associated with treatment completion in a community-based program for individuals with criminal justice involvement. Addiction Science \& Clinical Practice 2015 10(Suppl 1):A60

Submit your next manuscript to BioMed Central and take full advantage of:

- Convenient online submission

- Thorough peer review

- No space constraints or color figure charges

- Immediate publication on acceptance

- Inclusion in PubMed, CAS, Scopus and Google Scholar

- Research which is freely available for redistribution

Submit your manuscript at www.biomedcentral.com/submit
C Biomed Central 